\title{
Progesterone (P4), luteinizing hormone (LH) levels and ovarian activity in postpartum Santa Inês ewes subject to a male effect
}

\author{
José Carlos Ferreira-Silva ${ }^{1}$, Tracy Anne Burnett ${ }^{2}$, Paulo Francisco Maciel Póvoas Souto ${ }^{1}$, \\ Paulo Castelo Branco Gouveia Filho ${ }^{1}$, Lucas Carvalho Pereira ${ }^{3}$, Mariana Vieira Araujo ${ }^{3}$, \\ Marcelo Tigre Moura ${ }^{1}$, and Marcos Antonio Lemos Oliveira ${ }^{1}$ \\ ${ }^{1}$ Laboratório de Biotécnicas Aplicadas à Reprodução, Universidade Federal Rural de Pernambuco, \\ Recife, PE, Brasil \\ ${ }^{2}$ Faculty of Land and Food Systems. University of British Columbia, Vancouver, BC, V6T 1Z4, Canada \\ ${ }^{3}$ Laboratório Nordeste In Vitro, Maceió, AL, Brasil \\ Correspondence to: José Carlos Ferreira-Silva (carlos.ztec@gmail.com)
}

Received: 26 August 2016 - Revised: 31 March 2017 - Accepted: 6 April 2017 - Published: 2 May 2017

\begin{abstract}
This study aimed to establish P4 and luteinizing hormone (LH) levels and ovarian activity as approaches to monitor the cyclicity of ewes under postpartum anestrus after the male effect approach. Santa Inês females $(n=66)$ were evenly distributed into experimental groups where they were brought into contact with an intact male during the postpartum period of 35 to 40 days (T1) and 55 and 60 days postpartum (T2). Ewes were isolated from males for 30 days before the onset of the experiment. Estrus events were detected in $93.30 \%$ (T1) and $100 \%$ (T2) of females. Mean P4 concentrations $\left(\eta \mathrm{g} \mathrm{mL}^{-1}\right)$ before and after mating were $0.53 \pm 0.17$ and $4.55 \pm 0.24$ (T1) and $0.73 \pm 0.06$ and $4.90 \pm 0.11$ (T2), respectively, and concentrations were found to be lower $(P<0.05)$ before contact between genders. Preovulatory peaks of LH $\left(\eta \mathrm{g} \mathrm{mL}^{-1}\right)$ were evaluated at 42 (T2) and at $80 \mathrm{~h}$ (T1) after exposure to males, with mean ovulatory follicles of $7.90 \pm 0.31$ (T1) and $8.50 \pm 0.30 \mathrm{~mm}$ (T2) and a mean number of ovulations of $1.50 \pm 0.54$ (T1) and $1.60 \pm 0.51$ (T2). Pregnancy rates were $85.70 \%$ (T1) and $93.3 \%$ (T2), with no difference $(P>0.05)$ between groups. Results showed that the male effect was effective for inducing and concentrating the occurrence of estrus in postpartum ewes that had lambed within 35 to 60 days previously. Moreover, preovulatory LH peaks occurred within $80 \mathrm{~h}$ after physical contact between genders, which led to follicle luteinization and increased $\mathrm{P} 4$ concentration, without compromising pregnancy rates. The male effect can be used with postpartum ewes that had lambed within 35 to 40 days previously in order to decrease time between deliveries.
\end{abstract}

\section{Introduction}

Traditional sheep production in South America is predominantly sustained by production systems in extensive areas with low reproductive efficiency (Rubianes and Ungerfeld, 2002). Moreover, seasonal reproduction systems and long postpartum anestrus periods are factors that affect sheep production by reducing overall lambing rates. Shorter periods of sexual inactivity, the anticipation of the onset of the breeding season and increased prolificacy are economically relevant factors that allow profitability in such commercial settings
(Oliveira et al., 2015; Tenório Filho et al., 2016; FerreiraSilva et al., 2016). These factors are particularly true when carried out under adequate management practices and when those technologies are of low cost and simply executed (Simplício, 2008).

Hair sheep breeds have the potential to produce highquality meat and skin; they are also hardy animals and of great adaptive capacity to tropical regions, such as the northeast of Brazil (Machado et al., 1999). From a productive standpoint, the Santa Inês breed, which originated from crosses of exotic and Brazilian native breeds, is character- 
ized by a large size, where ewes weigh from 40 to $60 \mathrm{~kg}$ and rams from 80 to $100 \mathrm{~kg}$, although they may reach $120 \mathrm{~kg}$ (Figueiredo et al., 1983). From a reproductive standpoint, ewes are continuously polyestrous, with prolificacy varying from 1.3 to 1.4 , and have maternal ability (Ferreira-Silva et al., 2016, 2017).

Sheep production can be improved by genetic selection for ewes of improved reproductive efficiency, with lower age at first lambing, shorter time between deliveries and increased prolificacy (Notter and Copenhaver, 1980; Azzarini, 2004). The male effect alone (Sasa et al., 2011; Caldas et al. 2015a, b) or combined with pharmaceuticals (Knights et al., 2001; Ungerfeld et al., 2004; Monreal et al., 2009; FerreiraSilva et al., 2017) is a simple, effective and low-cost approach to reducing the duration of postpartum anestrus without affecting pregnancy rates (Caldas et al., 2015a, b).

The sudden introduction of males into a female flock of sheep where the animals are in anestrus results in an immediate increase in luteinizing hormone $(\mathrm{LH})$ pulse frequency and amplitude at intervals of 54-72 h (Knight et al., 1983) followed by ovulation (Martin et al., 1983; Moraes, 1991; Thimonier, 2000). This variation in LH pulses may be due to silent estrus behavior in ewes under anestrus (Knight et al., 1983; Thimonier, 2000). Thus, depending upon the resulting type of corpus luteum that is formed, females may have displayed short or normal estrous cycles (Caldas et al., 2015a, b), accompanied by an increase in P4 concentration (Sasa et al., 2011).

In face of the ongoing demand to reduce the interval between deliveries to increase sheep reproductive efficiency, the male effect could be used to shorten anestrus postpartum in ewes. Furthermore, to our knowledge, there is no report that used the male effect for this purpose in hair sheep, and the hormone levels and ovarian activity within this period remain to be described. This study aimed to evaluate changes in the cyclicity of anestrus postpartum Santa Inês ewes after the introduction of an intact male by determining P4 and LH profiles and ovarian activity.

\section{Material and methods}

Experiments were conducted in Escada, Pernambuco state, Brazil. The geographic coordinates are $08^{\circ} 21^{\prime} 33^{\prime \prime} \mathrm{S}$, $35^{\circ} 13^{\prime} 25^{\prime \prime} \mathrm{W}$; the altitude is $109 \mathrm{~m}$, the mean annual temperature $24.4^{\circ} \mathrm{C}$ and the mean annual rainfall $1763 \mathrm{~mm}^{3}$. Climactic conditions are tropical and semi-humid, with a rainy period from May to August.

Animals were raised on pastures during daylight hours and kept in a barn during the late afternoon. Nutrition was based upon cultivated (Brachiaria humidicola, Pennisetum purpureum) and native pastures (Paspalum maritimum, Chloris orthonton, Cynodon dactylon, Brachiaria tunnergrass). Mineral salt and water were offered ad libitum.
Postpartum ewes of 2 to 3 years of age were initially evaluated for body condition score and were preselected if they displayed a score of 2 or 3 , as described by Caldas et al. $(2015 \mathrm{a}, \mathrm{b})$. The anestrus condition was evaluated by reproductive tract ultrasonography following Santos et al. (2004). Selected ewes were identified with numbered plastic ear tags and colored neckband in order to ease management. Male effect preconditioning was established by isolating ewes from rams for 30 days at a distance of $10 \mathrm{~m}$, which avoids physical contact between genders as previously described by Caldas et al. (2015b). Santa Inês rams $(n=2)$ were preselected according to fertility records and were subject to an andrology exam a week before the onset of the experiment.

Cyclicity status was determined based upon P4 concentrations in addition to ultrasonography. Blood samples were collected on days 10, 20 and 30 during the male effect preconditioning period. Blood plasma was stored before analysis at $-20^{\circ} \mathrm{C}$. Progesterone (P4) concentration was determined in duplicates using radioimmunoassay. Females were considered in anestrus when they displayed serum concentrations lower than $1 \eta \mathrm{g} \mathrm{mL}^{-1}$ in two consecutive samples as described by Morales et al. (2003). After P4 concentration analysis, ewes $(n=66)$ were allocated to two groups: T1 (35-40 days after lambing) and T2 (55-60 days after lambing).

Rams were marked with a mixture of grease and ink $(4: 1)$ around the sternum and then introduced to the ewe flocks, with a male-to-female ratio of $1: 33$. Rams were marked with different ink colors and exchanged between ewe flocks on days 10, 20 and 30 of the breeding season (BS).

Blood plasma LH analysis was determined by duplicate double-antibody radioimmunoassay, following De St Jorre et al. (2012), and the limit of detection was $0.27 \eta \mathrm{g} \mathrm{mL}^{-1}$; the intra-assay and inter-assay coefficients of variation were 3.5 and $8.74 \%$, respectively. Variations in LH levels were considered significant when they increased by $20 \eta \mathrm{g} \mathrm{mL}^{-1}$ or more for two consecutive measurements, as suggested by Martin et al. (1983). Three ewes from each group were randomly chosen for LH analysis after the introduction of rams. Blood sampling for $\mathrm{LH}$ analysis was at $4 \mathrm{~h}$ intervals and performed during a period of 4 days after the introduction of rams, as described by Chanvallon et al. (2011) and Fabre-Nys et al. $(2015,2016)$. Moreover, ewes used for LH evaluation were excluded from further analysis in order to avoid any effect of excessive handling on estrus and pregnancy rates.

In order to estimate ovulation rates on ewes after mating, P4 concentration was also measured on days 10, 20 and 30 after the onset of the male effect as described above for LH analysis. Ewes were considered to have entered a cycle when they displayed a $\mathrm{P} 4$ concentration of $1 \eta \mathrm{g} \mathrm{mL}^{-1}$ or higher in two consecutive samples.

Ovarian activity was evaluated daily by ultrasonographic exams after estrous detection in six females of each group. The same technician performed all exams and the moment 
Table 1. P4 concentrations in Santa Inês postpartum ewes in anestrus that had delivered within 35 to 40 (T1) and 55 to 60 days (T2) previously and were further subject to the male effect.

\begin{tabular}{lccc}
\hline Group & Animals & \multicolumn{2}{c}{ P4 concentration $\left(\eta \mathrm{g} \mathrm{mL}^{-1}\right)$} \\
\cline { 3 - 4 } & $(n)$ & $\begin{array}{c}\text { Before male effect } \\
(\bar{x} \pm s)\end{array}$ & $\begin{array}{c}\text { After male effect } \\
(\bar{x} \pm s)\end{array}$ \\
\hline T1 & 30 & $0.53 \pm 0.17^{\mathrm{a}, \mathrm{c}}$ & $4.55 \pm 0.24^{\mathrm{b}, \mathrm{c}}$ \\
$\mathrm{T} 2$ & 30 & $0.73 \pm 0.06^{\mathrm{a}, \mathrm{d}}$ & $4.90 \pm 0.11^{\mathrm{b}, \mathrm{d}}$ \\
\hline
\end{tabular}

Different superscripts ${ }^{a, b}$ letters in the same row and superscripts letters ${ }^{c, d}$ in the same column denote statistical difference $(P<0.05)$.

of ovulation was defined according to Tenório Filho et al. (2007).

Ewes were observed twice daily for estrus (06:00 and 16:00 LT) by trained technicians during a breeding season (BS) of 35 days. Estrus events were considered synchronized when detected within the initial 5 days of the BS. Pregnancy diagnosis was made by ultrasonography on days 35 and 60 after mating as described by Santos et al. (2004).

Parametric variables were submitted to analysis of variance (ANOVA) and compared by the Student-NewmanKeuls (SNK) test with the System for Statistical Analysis (SAEG) software, with results presented as means and standard deviation $(\bar{x} \pm s)$. Nonparametric variables were evaluated using the chi-square test and presented as percentages (\%). Differences were considered significant when displayed probabilities were lower than $5 \%$.

\section{Results}

Concentrations of $\mathrm{P} 4$, which were assessed before BS onset in order to determine the cyclicity status of postpartum ewes are summarized in Table 1. Mean P4 concentrations were lower than $1 \eta \mathrm{g} \mathrm{mL}^{-1}$, indicating that all ewes were in anestrus before BS, irrespectively of the postpartum period. However, after the male effect, ewes cycled and ovulated, as demonstrated by increased $\mathrm{P} 4$ levels $(P<0.05)$.

Concentrations of LH were also measured after ewes were subject to the male effect. Despite varying postpartum periods, the male effect induced LH preovulatory peaks between 52 and $80 \mathrm{~h}$ after the onset of the BS (Fig. 1).

The incidence of estrus during the BS was also determined (Fig. 2). Estrus events were detected until day 33 of the BS. Estrus events were detected in 93.30 and $100 \%$ of ewes in the $\mathrm{T} 1$ and T2 groups, respectively. An increased incidence of estrus was observed in T2 within the initial 10 days of the BS. First estrus occurred between days 1 and 33, with the mean for first estrus being $15.45 \pm 10.36$ (T1) and $9.25 \pm 6.41$ (T2) days post-lambing. The overall incidence of synchronized estrus was $23 \%$ for all ewes, with $26 \%$ in T1 and $20 \%$ in T2, with no difference between groups $(P>0.05)$.
Table 2. Mean values for follicular diameter ( $\mathrm{mm}$ ) and ovulation in Santa Inês postpartum ewes in anestrus that had delivered within 35 to 40 (T1) and 55 to 60 (T2) days previously and were further subject to the male effect.

\begin{tabular}{lcccc}
\hline Group & \multicolumn{4}{c}{ Ovarian activity } \\
\cline { 2 - 5 } & $\begin{array}{c}\text { Large follicle } \\
\text { diameter } \\
(\bar{x} \pm s)\end{array}$ & $\begin{array}{c}\text { Second large } \\
\text { follicle } \\
\text { diameter } \\
\end{array}$ & $\begin{array}{c}\text { Follicular } \\
\text { diameter } \\
(\bar{x} \pm s)\end{array}$ & $\begin{array}{c}\text { Ovulations } \\
(\bar{x} \pm s)\end{array}$ \\
& \multicolumn{4}{c}{} \\
\hline T1 & $7.9 \pm 0.31^{\mathrm{a}}$ & $7.6 \pm 0.41^{\mathrm{a}}$ & $7.8 \pm 0.38^{\mathrm{a}}$ & $1.5 \pm 0.54^{\mathrm{a}}$ \\
$\mathrm{T} 2$ & $8.5 \pm 0.30^{\mathrm{b}}$ & $8.0 \pm 0.25^{\mathrm{a}}$ & $8.3 \pm 0.37^{\mathrm{b}}$ & $1.6 \pm 0.51^{\mathrm{a}}$ \\
\hline Different superscript letters on same column denote statistical difference $(P<0.05)$.
\end{tabular}

Table 3. Pregnancy rates of Santa Inês postpartum ewes in anestrus that had delivered within 35 to 40 (T1) and 55 to 60 (T2) days previously and were further subject to the male effect.

\begin{tabular}{llll}
\hline \multirow{2}{*}{ Group } & \multicolumn{3}{c}{ Pregnancy per service } \\
\cline { 2 - 4 } & First & Second & Total \\
& $\mathrm{n} / \mathrm{n}(\%)$ & $\mathrm{n} / \mathrm{n}(\%)$ & $\mathrm{n} / \mathrm{n}(\%)$ \\
\hline T1 & $18 / 20(90.0)$ & $6 / 8(75.0)$ & $24 / 28(85.7)$ \\
T2 & $24 / 25(96.0)$ & $4 / 5(80.0)$ & $28 / 30(93.3)$ \\
\hline
\end{tabular}

Ovarian activity was monitored in order to correlate it with estrus and pregnancy rates (Table 2). Large follicles $(P<0.05)$ were detected on T2, but the second large follicle did not differ between groups. The mean number of ovulations was similar between groups $(P>0.05)$. Pregnancy rates were determined after first and second mating throughout the BS (Table 3), but no difference was observed $(P>0.05)$ between groups.

\section{Discussion}

Monitoring reproductive activity by $\mathrm{P} 4$ concentration has been used to detect anestrus in ewes, in relation to seasonal factors or postpartum condition (Sasa et al., 2011). As described here, mean $\mathrm{P} 4$ concentrations before the male effect demonstrated that ewes were in anestrus, based upon P4 levels previously described by Morales et al. (2003). However, the exposure of ewes to the male effect, irrespective of the postpartum period, led to a significant increase in P4 levels, which is in accordance with previous reports (Sasa et al., 2002).

There is strong evidence correlating $\mathrm{P} 4$ concentrations to sexual behavior in anestrus ewes, as $\mathrm{P} 4$ stimulates receptivity to rams and increases estrous behavior (Fabre-Nys and Martin, 1991a, b; Caraty and Skinner, 1999). The total incidence of estrus was similar between groups. However, most estrus events within $\mathrm{T} 2$ were concentrated in the initial 10 days of the BS, in agreement with their higher $\mathrm{P} 4$ concentrations. Since all ewes were in anestrus prior to treatment, it was ex- 


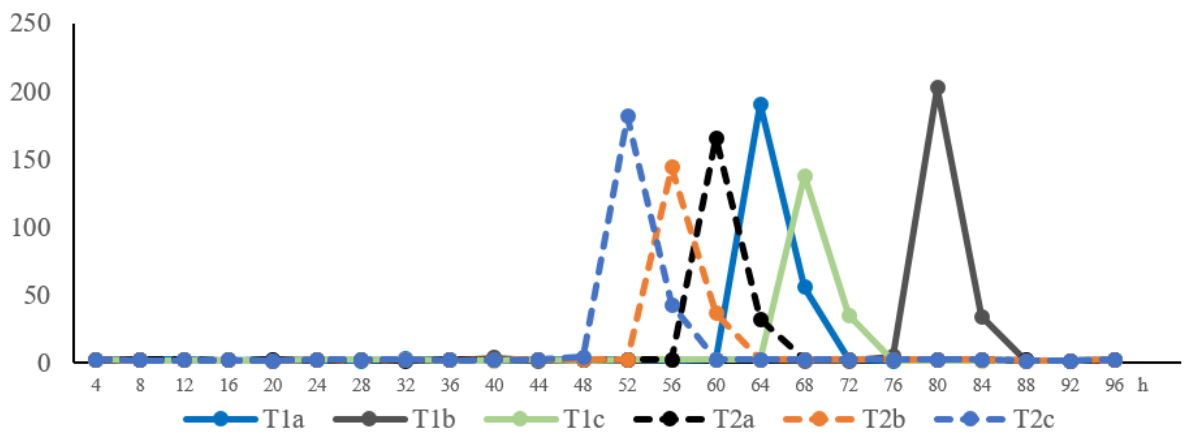

Figure 1. Individual LH concentration $\left(\eta \mathrm{g} \mathrm{mL}^{-1}\right)$ during the period of 4 to $96 \mathrm{~h}$ after the onset of the male effect in Santa Inês postpartum ewes in anestrus $(n=6)$ that had delivered within 35 to 40 days (T1) and 55 to 60 days (T2) previously.

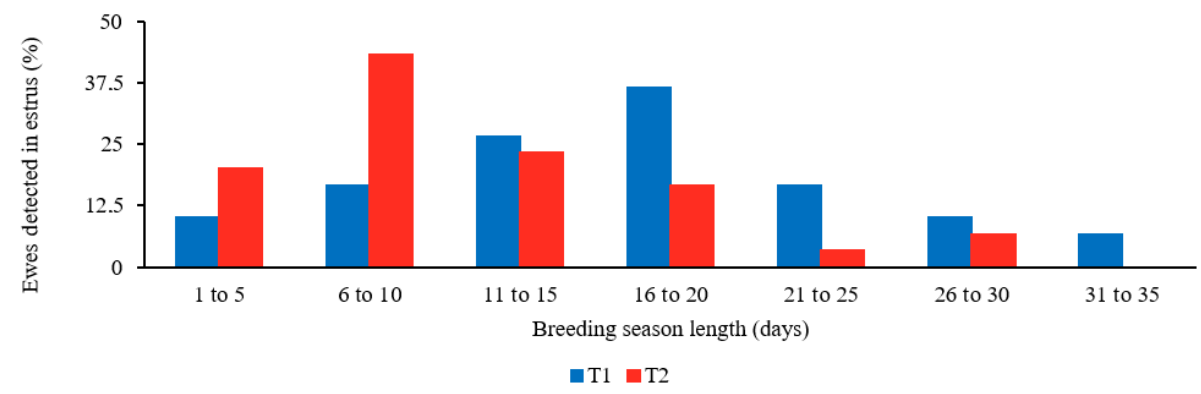

Figure 2. Distribution of estrus events in Santa Inês postpartum ewes in anestrus after being subject to the male effect and 35 to 40 days (T1) and 55 to 60 days (T2) after delivery.

pected that, irrespective to the number of days postpartum, ewes would display a similar responsiveness to the male effect. However, more encouraging results were described with cycling ewes (Caldas et al., 2015a, b) for estrus incidence within the initial 10 days of the BS and estrus synchronization within the initial 5 days of the BS.

The presence of $\mathrm{P} 4$ is required to induce GnRH production (Caraty and Skinner, 1999), which is responsible for the subsequent LH preovulatory peak (Martin et al., 1983). The data described here show that the LH preovulatory peak was induced approximately $30 \mathrm{~h}$ in advance in ewes that showed higher P4 concentrations before the male effect. Moreover, these ewes were under prolonged postpartum anestrus, a fact that may have contributed to this observation, since these ewes were expected to show higher basal LH levels than ewes under more recent postpartum periods. This hypothesis is in accordance with Martin et al. (1980), who found that higher basal LH levels before interaction between genders increased responsiveness to the male effect. Despite differences in $\mathrm{LH}$ preovulatory kinetics, mean LH concentrations were similar between groups and all ewes showed LH preovulatory peaks within $80 \mathrm{~h}$ after the male effect onset, as previously described by Oldham et al. (1979). This similarity between results is in agreement with similar incidences of short estrus cycles and the number of ovulations between groups. Due to these facts, the determination of $\mathrm{LH}$ levels at $4 \mathrm{~h}$ intervals was efficient to capture the preovulatory peak as described in other reports (Chanvallon et al., 2011; Fabre-Nys et al., 2015).

Although LH preovulatory peaks occurred later in ewes with more recent delivery, it may not have contributed to oocyte competence during follicle growth or luteinization, even after the use of exogenous P4 in association with the male effect (Skinner et al., 2000). Accordingly, the large follicle diameter was large in ewes under prolonged postpartum period conditions and did not affect pregnancy viability, since $\mathrm{P} 4$ produced after follicle luteinization was sufficient to maintain full-term pregnancies at similar rates.

\section{Conclusions}

The male effect is efficient to induce and concentrate estrus within a small window of time in postpartum ewes within 35 to 60 days after lambing. Under these conditions, the LH preovulatory peak occurs within $80 \mathrm{~h}$, which ultimately leads to follicle luteinization and further increases in P4 synthesis. Moreover, postpartum ewes can be subjected to the male effect in order to reduce the time between deliveries, with no effect on overall pregnancy rates. 
Data availability. The research data described in the article are available for those who request it. Any concerns about our work will be addressed accordingly in due time.

Competing interests. The authors declare that there is no conflict of interest and are available to provide any clarification.

Acknowledgements. The authors are grateful to CNPq for financial support of this study.

This research was performed after evaluation and approval of the Ethics Committee of the Faculdade Pio Décimo, Aracaju-Se, Brazil, with protocol no. 08/12.

Edited by: M. Mielenz

Reviewed by: E. Kuznicka and one anonymous referee

\section{References}

Azzarini, M.: Potencial reproductivo de los ovinos, Produc. Ovin., $16,5-17,2004$

Caldas, E. L. C., Ferreira-Silva, J. C., Freitas Neto, L. M., Veloso Neto, H. F., Moura, M. T., Lima, P. F., Santos, M. H. B., and Oliveira, M. A. L.: Male effect associated with suckling interruption on the reproductive performance of santa inês ewes, B. Indústr. Anim., 72, 117-123, doi:10.17523/bia.v72n2p117, 2015a.

Caldas, E. L. C., Freitas Neto, L. M., Almeida-Irmão, J. M., Ferreira-Silva, J. C., Silva, P. G. C., Veloso Neto, H. F., Neves, J. P., Moura, M. T., Lima, P. F., and Oliveira, M. A. L.: The influence of separation distance during the preconditioning period of the male effect approach on reproductive performance in sheep, Vet. Sci. Dev., 4, 1-9, doi:10.4081/vsd.2015.5515, 2015b.

Caraty, A. and Skinner, D. C.: Progesterone priming is essential for the full expression of the positive feedback effect of estradiol in inducing the preovulatory gonadotropin-releasing hormone surge in the ewe, Endocrinology, 140, 165-170, doi:10.1210/endo.140.1.6444, 1999.

Chanvallon, A., Sagot, L., Pottier, E., Debus, N., François, D., Fassier, T., Scaramuzzi, R. J., and Fabre-Nys, C.: New insights into the influence of breed and time of the year on the response of ewes to the 'ram effect', Animal, 5, 1594-1604, doi:10.1017/S1751731111000668, 2011.

De St Jorre, T. J., Hawken, P., and Martin, G. B.: Role of male novelty and familiarity in male-induced LH secretion in female sheep, Reprod. Fertil. Dev., 24, 523-530, doi:10.1071/RD11085, 2012.

Fabre-Nys, C. and Martin, G. B.: Hormonal control of proceptive and receptive sexual behavior and the preovulatory $\mathrm{LH}$ surge in the ewe: reassessment of the respective roles of estradiol, testosterone, and progesterone, Horm. Behav., 25, 295-312, doi:10.1016/0018-506X(91)90003-Z, 1991a.

Fabre-Nys, C. and Martin, G. B.: Roles of progesterone and oestradiol in determining the temporal sequence and quantitative expression of sexual receptivity and the preovulatory LH surge in the ewe, J. Endocrinol., 130, 367-379, doi:10.1677/joe.0.1300367, 1991b.
Fabre-Nys, C., Chanvallon, A., Dupont, J., Lardic, L., Lomet, D., Martinet, S., and Scaramuzzi, R. J.: The "Ram Effect": A "NonClassical" Mechanism for Inducing LH Surges in Sheep, PloS One, 11, e0158530, doi:10.1371/journal.pone.0158530, 2016.

Fabre-Nys, C., Kendrick, K. M., and Scaramuzzi, R. J.: The "ram effect": new insights into neural modulation of the gonadotropic axis by male odors and socio-sexual interactions, Front. Neurosci., 9, 111, doi:10.3389/fnins.2015.00111, 2015.

Ferreira-Silva, J. C., Chaves, M. S., Tenório Filho, F., Moura, M. T., Neto, L. F., Caldas, E. L. C., and Oliveira, M. A. L.: Reproductive efficiency of non-cycling postpartum ewes submitted to the male effect under tropical semi humid conditions, Livestock Res. Rural. Dev., 28, 171, 2016.

Ferreira-Silva, J. C., Basto, S. R. L., Tenório Filho, F., Moura, M. T., Silva Filho, M. L., and Oliveira, M. A. L.: Reproductive performance of postpartum ewes treated with insulin or progesterone hormones in association with ram effect have been received, Reprod. Domest. Anim., in press, 2017.

Figueiredo, E. D., Oliveira, E. D., Bellaver, C., and Simplicio, A. A.: Hair sheep performance in Brazil, in: Hair sheep of Western Africa and the Americas, edited by: Fitzhugh, H. A. and Bradford, G. E., Westview Press, Boulder, Colorado, 125-140, 1983.

Knight, T. W., Tervit, H. R., and Lynch, P. R.: Effect of boar pheromones, ram's wool and presence of bucks on ovarian activity in anovular ewes early in the breeding season, Anim. Reprod. Sci., 6, 129-134, doi:10.1016/0378-4320(83)90017-9, 1983.

Knights, M., Hoehn, T., Lewis, P. E., and Inskeep, E. K.: Effectiveness of intravaginal progesterone inserts and $\mathrm{FSH}$ for inducing synchronized estrus and increasing lambing rate in anestrous ewes, J. Anim. Sci., 79, 1120-1131, doi:10.2527/2001.7951120x, 2001.

Machado, J. B. B., Fernandes, A. A. O., Selaive-Villarroel, A. B., Costa, A. L., Lima, R. N., and Lopes, E. A.: Parâmetros reprodutivos de ovinos deslanados Morada Nova e Santa Inês mantidos em pastagem cultivada no estado do Ceará, Rev. Cient. Prod. Anim., 1, 81-87, 1999.

Martin, G. B., Oldham, C. M., and Lindsay, D. R.: Increased plasma LH levels in seasonally anovular Merino ewes following the introduction of rams, Anim. Reprod. Sci., 3, 125-132, doi:10.1016/0378-4320(80)90039-1, 1980.

Martin, G. B., Scaramuzzi, R. J., and Henstridge, J. D.: Effects of oestradiol, progesterone and androstenedione on the pulsatile secretion of luteinizing hormone in ovariectomized ewes during spring and autumn, J. Endocrinol., 96, 181-193, doi:10.1677/joe.0.0960181, 1983.

Monreal, A. C. D., Carneiro, L. O. H. B., and Redondo, M. V. S.: Efeito macho associado ao emprego de progesterona intravaginal em ovelhas, sob latitude $20^{\circ} 52^{\prime}$, South. Agrarian, 2, 143-152, 2009.

Moraes, J. C. F.: Emprego do "efeito carneiro" na indução e manipulação do ciclo estral em ovelhas durante o anestro, A Hora Veterinária, 11, 32-34, 1991.

Morales, J. U., Váquez, H. G. G., and Andrade, B. M. R.: Influencia del pastoreo restringido en el efecto macho em cabras em baja condición corporal durante la estación de anestro, Téc. Pecu. Méx., 41, 251-260, 2003.

Notter, D. R. and Copenhaver, J. S.: Performance of Finnish Landrace crossbred ewes under accelerated lambing. 
II. Lamb growth and survival, J. Anim. Sci., 51, 1043-1050, doi:10.2527/jas1980.5151043x,1980.

Oldham, C., Martin, G. B., and Knight, T. W.: Stimulation of seasonally anovular Merino ewes by rams. I. Time from introduction of the rams to the preovulatory LH surge and ovulation, Anim. Reprod. Sci., 1, 283-290, doi:10.1016/0378-4320(79)90013-7, 1979.

Oliveira, L. R. S., Ferreira-Silva, J. C., Chaves, M. S., Freitas Neto, L. M., Moura, M. T., Caldas, E. L. C., Lima, P. F., and Oliveira, M. A. L.: Male Effect and Breeding Season Shortening Under Contrasting Climatic Conditions Upon Reproduction of Nulliparous Anglo-Nubians, Ciênc. Vet. Tróp., 18, 43-48, 2015.

Rubianes, E. and Ungerfeld, R.: Perspectivas de la investigacíon sobre reproducción ovina em América Latina en El marco de las actuales tendências productivas, Arch. Latinoam. Prod. Anim., 10, 117-125, 2002.

Santos, M. H. B., Oliveira, M. A. L., Moraes, E. P. B. X., Moura, R. T. D., Lima, P. F., and Reichenbach, H.-D.: Diagnóstico de gestação por ultra-sonografia de tempo real, in: Diagnóstico de gestação na cabra e na ovelha, edited by: Santos, M. H. B., Oliveira, M. A. L., and Lima, P. F., Varela, São Paulo, 97-116, 2004.

Sasa, A., Teston, D. C., Rodrigues, P. D. A., Coelho, L. D. A., and Schalch, E.: Concentrações plasmáticas de progesterona em borregas lanadas e deslanadas no período de abril a novembro, no Estado de São Paulo, R. Bras. Zootec., 31, 1150-1156, doi:10.1590/S1516-35982002000500011, 2002.

Sasa, A., Nonaka, K. O., Balieiro, J. C. C., and Coelho, L. A.: Progesterona plasmática de ovelhas submetidas ao efeitomacho e mantidas sob diferentes condições nutricionais, Arq. Bras. Med. Vet. Zootec., 63, 1066-1072, doi:10.1590/S010209352011000500004, 2011.
Simplício, A. A.: Estratégias de manejo reprodutivo como ferramenta para prolongar o período de oferta de carnes caprina e ovina no Brasil, Rev. Tecnol. Ciên. Agropec., 2, 29-39, 2008.

Skinner, D. C., Harris, T. G., and Evans, N. P.: Duration and amplitude of the luteal phase progesterone increment times the estradiol-induced luteinizing hormone surge in ewes, Biol. Reprod., 63, 1135-1142, doi:10.1095/biolreprod63.4.1135, 2000.

Tenório Filho, F., Santos, M. H. B., Carrazzoni, P. G., Bartolomeu, C. C., Lima, P. F., and Oliveira, M. A. L.: Follicular dynamics in Anglo-Nubian goats using transrectal and transvaginal ultrasound, Small Ruminant Res., 72, 51-56, doi:10.1016/j.smallrumres.2006.08.007, 2007.

Tenório Filho, F., Ferreira-Silva, J. C., Nascimento, P. S., Freitas Neto, L. M., Moura, M. T., Almeida Irmão, J. M., and Oliveira, M. A. L.: Ação do efeito macho sobre a eficiência reprodutiva de ovelhas nulíparas das raças Santa Inês e Morada Nova criadas em diferentes regiões, Acta Scientiae Veterinariae, 44, 1353, 2016.

Thimonier, J.: Détermination de l'état physiologique des femelles par analyse des niveaux de progestérone, INRA Produção Animal, 13, 177-183, 2000.

Ungerfeld, R., Forsberg, M., and Rubianes, E.: Overview of the response of anoestrous ewes to the ram effect, Reprod. Fert. Dev., 16, 479-490, doi:10.10371/RD04039, 2004. 